\title{
New Developments and Trends in Tissue Engineering: An Update
}

\section{Raymund E Horch*}

Raymund E Horch, Professor of Plastic and Hand Surgery, Director and Chairman, Department of Plastic and Hand Surgery and Laboratory of Tissue Engineering and Regeneration Medicine, Friedrich-Alexander University of Erlangen-Nuernberg, Krankenhausstrasse 12, D-91054Erlangen, Germany

For the creation of a theory the mere collection of recorded phenomena never suffices - there must always be added a free invention of the human mind that attacks the heart of the matter.

\section{-Albert Einstein}

Although it is now known as a common term for almost two decades, 'Tissue Engineering' (TE) still can be considered to be a comparatively young field of basic and applied multidisciplinary biomedical research. It utilizes the principles and methods of engineering and life sciences combined with clinical expertise toward the development of biological tissue substitutes to restore, maintain or improve the function of diseased or damaged human tissues is currently leaving its eggshells behind [1]. Without doubt the collaboration of scientists from many various disciplines has led to the development of a multitude of brilliant inventions, latest research tools and scientific techniques which are now constantly incorporated in this yet growing scientific field [2]. Whereas the first clinically relevant efforts in TE were based on the generation of bioengineered skin substitutes for severely burned patients, the field has significantly evolved over the past 20 years with an enormous extension of ideas and application of these principles to a wide variety of tissues and organs. Typical examples of tissue engineered substitutes that have been and still are currently being investigated (- and have in part already been clinically applied -) throughout the world now include skin, cartilage, bone, blood vessels, pancreas, heart valves, breast, nerves, trachea, bowel, kidney, lung and liver. This went along with an increase in engineering a multitude of different biomaterials as potential cell-seeding-scaffolds on the one hand and sophisticated techniques on the other hand with regard to various culture media and two- and three dimensional cell cultures as well as the establishment of bioreactors. On this way the capacity of cell renewal even in adult and differentiated cells has led to new insights into the "stem cell potential" of adult mammalian cells, especially mesenchymal stem cells that are now a common topic in TE. In addition to this the ever increasing knowledge about embryonic stem cells (ESC) has added one more dimension to foster tissue and organ regeneration alone or in combination with TE techniques [3]. However, ethical issues with the use of ESC have not been fully discussed (zitation horch ethical issues). This shows that new tools are constantly integrated into common TE approaches which are merging the field more or less into the term Regenerative Medicine (RM). The concept of RM is a fascinating and a fast-moving subject matter, since it can been observed as a rapidly growing and fast-moving interdisciplinary field of studies, involving stem cell research, tissue engineering, biomaterials, would healing, and patient-specific drug discovery [4-6].

There was considerable initial enthusiasm and many promising achievements during the pioneering phases similar to any emerging area of science, that, however, were followed by several drawbacks during the translation into clinical applications. When it came to the clinical implantation of cultured tissue surrogates, the practical performance proved much more challenging than was initially estimated. However, such seemingly unforeseen obstacles paved the way for new solutions. Even in seemingly simple TE substitutes such as epithelial sheet grafts without necessary three-dimensional vascular (micro) networks new alternatives for cell and tissue delivery from the laboratory were created [7]. Instead of transplanting readymade multilayer epithelial sheets it turned out that delivering single cell as a suspension in a biological carrier perform better and are easier to handle [7-12].

On the other side, insights gained from TE experiments have been also applied to various forms of medical therapies, such as direct organ or tissue replacement. Research on material interactions $[13,14]$ under laboratory conditions have also fostered the improvement of medical devices. For instance vascular stents have been modified to better perform in the human being, which now contributes to an increasing number of procedures due to atherosclerosis or Coronary Artery Disease. Cells have been seeded onto tubular biopolymer scaffolds to generate vascular grafts with the help of smooth muscle cells and an inner lining produced by endothelial cells. This is one example where huge clinical needs could be met in the future. Others have studied the inner lining of synthetic vascular grafts by culturing endothelial cells under shear stress conditions, exerted to a closed cell monolayer. This is another example for the intermingling of basic science and clinical experience in form of a natural transition of TE from bench to bedside and back from bedside to bench.

In larger surrogate structures that are created in the laboratory as a tissue substitute we encounter the problem of sufficient initial supply of nutrients to the cells that are seeded within a 3-D scaffold. The critical time remains until sufficient vascular supply can be created from the recipient organism. The mechanistic attempt to combine endothelial cell seeding into tissue substitutes in order to achieve earlier vascular in growth is still not really feasible since there remains a significant time lag until vessels can grow from the outer perimeter of any scaffold into the middle of it. Although this idea could be worthwhile in a long term perspective, it is not yet clinically successful. This holds also true for the addition of various growth factors that may enhance any kind of vascularization. However growth factors do not prevent malnutrition in the initial phase after transplantation, since the substitute still depends on the ingrowths of capillaries from the recipient into the middle of any given construct. This is by any means still a process that takes at least several days to suffice.

To circumvent this initial nutritional problem some groups have introduced more surgically oriented approaches that encompass the

${ }^{*}$ Corresponding author: Raymund E Horch, Professor of Plastic and Hand Surgery, Director and Chairman, Department of Plastic and Hand Surgery and Laboratory of Tissue Engineering and Regeneration Medicine, Friedrich-Alexander University of Erlangen-Nuernberg, Krankenhausstrasse 12, D-91054Erlangen, Germany, Tel: +49 (0)9131 85 33277; Fax: +49 (0)9131 85 39327; E-mail Raymund.Horch@uk-erlangen.de

Received February 21, 2012; Accepted February 25, 2012; Published December February 27, 2012

Citation: Horch RE (2012) New Developments and Trends in Tissue Engineering: An Update. J Tissue Sci Eng 3:e110. doi:10.4172/2157-7552.1000e110

Copyright: $\odot 2012$ Horch RE, et al. This is an open-access article distributed under the terms of the Creative Commons Attribution License, which permits unrestricted use, distribution, and reproduction in any medium, provided the original author and source are credited. 
creation of a vascular network first and then allow the transplantation of a completely vascularized construct with microsurgical connection of arteries and veins. The so called arterio- venous loop model is, however, by far more complex and depends on an considerable microsurgical expertise [15]. The latter is necessary to guarantee successful vascular connections on a supamicrosurgical level [16]. After utilizing this technique in small animal models and in a clinically relevant scale in large animal models [17] the first clinical results with long term success over more than 4 years are now on the horizon and will be reported in the near future.

The advent of new technologies to handle adult mesenchymal or embryonic stem cells has raised an increased interest in mesenchymal stem cells for TE purposes, their role in stem cell niches and their differentiation into various lineages [18]. First identified in the bone marrow, where they are present with about ten-fold higher concentrations than in the circulation MSC can be obtained from nearly all tissues with varying frequencies $[19,20]$. However in adult human beings, the number of viable, freshly isolated cells is limited due to the dispensable bone marrow volume [21,22].

According to Tuljapurkar and coauthors [23] although originally MSC were used therapeutically for skeletal problems and gene therapy, but meanwhile multiple additional therapeutic applications have been evaluated. These include the promotion of hematopoietic recovery in stem cell transplant recipients severe, acute graft-versus-host disease, autoimmune diseases, muscle repair, skin wound healing, intestine healing following irradiation, stroke, myocardial ischemia $[24,25]$ as well as other diseases $[23,26-30]$.

The use of stem cells for tissue engineering and regeneration is especially attractive to substitute worn out tissues and to potentially regrow parts or whole organs by mechanisms formerly unknown in adult mammals. The prospects offered carry significant promise to advance our mechanistic understanding of the role of MSC in tissue repair and regenerative medicine. Numerous scientists worldwide have organized themselves in different societies for Regenerative Medicine and are advancing this field in biomedicine. Atala and co authors stated that the stem cell field is advancing rapidly and will open new avenues for this type of therapy with hitherto unknown possibilities $[3,31,32]$. For example, therapeutic cloning and cellular reprogramming could well provide a potentially limitless source of cells for tissue engineering applications in the future. While stem cells are still in the research phase, some therapies based on tissue engineering concepts have already entered the clinical stage successfully. That indicates the promise that regenerative medicine will hold for the future [32]. Among the issues that need to be further studied are questions of the isolation of cell lines, as well as cell line development in order to obtain adequate cell lines, tumorigenicity, immunosuppression, surface phenotyping, differentiation into specific cell lines (such as adipocytes, chondrocytes, and osteoblasts for example). Nevertheless, although numerous laboratories around the world are now engaged in the development of new tools such as stem cells and biologically active scaffolds it remains to be proven if this new technology really has passed the threshold of maturity as a clinical method to restore organ function in humans. Ethical issues with the use of embryonic stem cells are under discussion and not yet clearly answered with regard to clinical translation [33]. Despite potential hindrances the stem cell promise has now entered the field of TE and therefore the term Regenerative Medicine has been propagated as the superordinate concept $[5,34,35]$.

Scientists may now take fresh looks at well-known clinical problems of replacement of a large variety of organs. From the common perspective this will most likely be the regeneration of bone, skin, the spinal cord, peripheral nerves, articular cartilage, the conjunctiva, heart valves and urologic organs, to name a few aspects only. It will also be necessary to work out while still other the mechanistic pathways of regeneration and the theoretical implications of growing back organs in an adult [32].

But not only severe diseases have become a target for TE research efforts. For many reasons it seems attractive to enhance TE further towards not life threatening conditions. The demand for cosmetic surgery products has been projected alone in the U.S. to reach $\$ 3.07$ billion by 2012, while the cosmetic surgery procedures market is projected to reach $\$ 15.13$ billion by 2012 and there is much more increase expected in the Asian population [36-38]. Improvements in health and the related rise in life expectancy are among the most remarkable demographic changes of the past century [39]. For the world as a whole, life expectancy more than doubled from around 30 years in 1900 to 65 years by 2000 (and is projected to rise to 81 by the end of this century) [40].

With changing age structures, together with improvements in health, medical technology, life-style changes, and longevity among the elderly, for the first time in history, populations with large and growing rates of old age dependency have become a well known phenomenon [40]. Simultaneously the number of surgical procedures performed worldwide is increasing. Joint and bone replacement procedures (i.e. hip, knee and shoulder joints), which were little-known only a century ago, have now been implemented as standard treatment options for joint diseases or arthrosis worldwide. The need for functional bone substitutes is an important issue in this context. Taken alone affections of the bony skeletal system, there are approximately more than 1.500 .000 surgical procedures performed every year worldwide in which bone substitutes are required. Bone substitutes - which are far away from ideal and have many associated problems - are often required to help repair or replace damaged or diseased tissues in cases ranging from trauma, to congenital and degenerative diseases, to chronic wounds, to cancer, to cosmetics. Currently available bone substitutes, including autografts, allografts, and synthetic materials, are the most implanted materials second only to transfused blood products. Autografting, today's gold standard procedure, is naturally limited, expensive and can have significant donor site morbidity, and synthetic materials wear out and do not behave like true bone. Seeding biodegradable scaffolds with donor cells and/or growth factors, then culturing and implanting the scaffolds to induce and direct the growth of new, healthy tissue has been attempted by different groups, but the limiting factor up to now has been the lack of blood vessels in such $3 \mathrm{D}$-constructs.

Among the various efforts that have been undertaken to create large-scale, it has been shown that tissue engineered bone with a prevascularized microvascular pedicle can be formed through a unique system of prevascularization of the bony matrix before it is clinically implanted $[5,15,16,41-45]$. This may provide a viable bony substitute with blood vessels incorporated as an alternative for the current options.

Beside the developments in material science such as constructing scaffolds with the help of nano-technique [46,47], also stem cell research and genetic engineering will probably lead to hitherto unknown progress. Another fascinating prospect for TE related research is the advent of the research field of epigenetic, that offers a multitude of new perspectives to modulate cells for regenerative purposes $[48,49]$. It has come to light that genes may be mobile, exist in plasmids and cytoplasmic organelles, and can be imported by nonsexual means from other organisms or as synthetic products. 
Although the notion of epigenetics was originally given to any regulation beyond DNA sequence, it has often been restricted to chromatin modifications, supposed to behave as cis-markers, specifying the sets of genes to be expressed or repressed. This definition does not take into account the initial view of epigenetics, based on nonlinear interaction networks whose "attractors" can remain stable without need for any chromatin mark [50]. Epigenetics has reborn as a new field of developmental genetics.

The unorthodox prion proteins can even simulate some gene properties. Genetics was to an extent reincarnated as of the twenty-first century by assimilating the tools of cybernetics and of many formerly distant areas of science [49]. It refers to changes in phenotype or gene expression caused by mechanisms other than changes in the underlying DNA sequence, hence phenomena which can be induced during cell culture for TE or by interactions between cells and biomaterials. Epigenetic changes are preserved when cells divide. These changes may remain through cell divisions for the remainder of the cell's life and may also last for multiple generations. Cellular differentiation may serve as a typical example of epigenetic changes in eukaryotic cells [50]. The molecular basis of epigenetics is certainly complex, since it involves modifications of the activation of certain genes, but not the basic structure of DNA [49]. In the context of TE and RM, however, it can help us to better understand why the differentiated cells in a multicellular organism express only the genes that are necessary for their own activity as well as such processes involved in the unfolding development of an organism. Specific epigenetic processes include X-chromosomeinactivation, bookmarking, paramutation, imprinting, gene silencing, reprogramming, the progress of carcinogenesis, many effects of teratogens, regulation of histone modifications and heterochromatin, and technical limitations affecting parthenogenesis and cloning. Given the unforeseeable expectations of these developments it becomes clear that TE is steadily growing in relevance at the verge of many fields of biomedical research and medical science.

Hope comes also from other areas of research. A recent example is the discovery of Popescu and coauthors, who published the detection of a specialized type of cells, initially described as interstitial cells of Cajal, that are now called telocytes and were described to have been detected as a case of serendipity [51-67] (see http://www.telocytes. com). Understanding the possible action of Telocytes, which were found in many organs, such as in the upper and lower urinary tracts, blood vessels, pancreas, male and female reproductive tracts, mammary gland, placenta, and, recently, in the heart as well as in the gut will also further TE and RM prospects. Telocytes have been described as a special type of cells in the interstitium that show the presence of 2-5 cell body prolongations that are extremely thin. Since they were measured with a diameter of less than 0.2 mum (and thus under resolving power of light microscopy) they had not been detected before their specific morpholgy was revealed with the help of labor-intensive electron microscopy investigations. The prolongations are extremely long and show a monofiliform aspect with many dilations along, as well as caveolae [67]. In terms of RM experimental infarction models have been implemented to study the ultra structural recovery, especially neo-angiogenesis in the infarction border zone with regard to the potential role of such Telocytes (TC) [58]. Electron microscopy (EM), immunocytochemistry findings and analysis of several proangiogenic microRNAs seem to provide evidence for TC involvement in neoangiogenesis after myocardial infarction. These findings have been discussed to be an indicator for the lead to the speculation that Telocytes might play an important role in neo-angiogenesis during the late stage of myocardial infarction. The transition of this knowledge into TE and

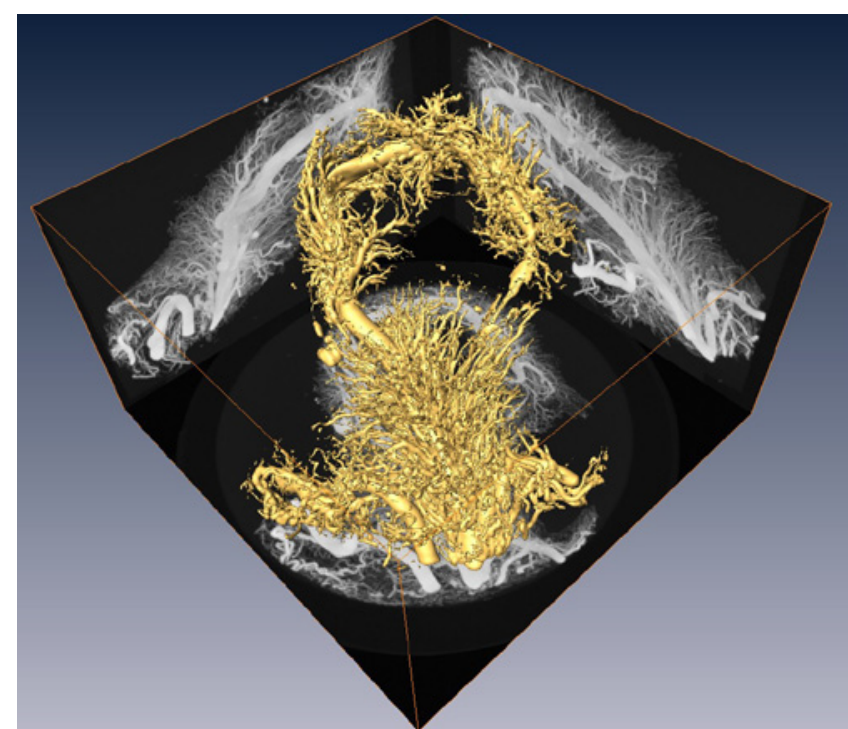

Figure 1: Three dimensional micro $\mathrm{Ct}$ of vascular growth and sprouting from an arteriovenous loop in tissue engineered bony construct (TricOS ${ }^{\circledR}$ matrix) without growth factors within an isolation chamber at 2 weeks after implantation (image kindly provided by Dr. Andreas Arkudas, Erlangen).

RM opens another perspective in solving common problems of tissue regeneration.

\section{Conclusion}

Although mankind has always been longing for simple and easy ways to restore their youth and get rid of degenerative problems (Figure 1) there is still a long but promising way to go, unveiling the secrets of regeneration to be available for customized problems. It seems obvious to utilize all the enormous technical expertise that has been gained from the field of TE and RM for more than tissue replacement only. Many consolidated findings that stem from TE have enhanced the comprehension of molecular and cellular processes related to various diseases and physiological processes. Not only may such knowledge be applied to different forms of medical treatment, such as creating intelligent biological drug delivery systems, but also will it be helpful to better understand mechanisms such as apoptosis and carcinogenesis [68]. It may help us to explain mechanisms of aging, human development, and the origins of cancer, heart disease, mental illness, as well as several other conditions. Hopefully it may help to successfully treat degenerative and malignant diseases in the future. Since like in any emerging scientific field no progress can be made without substantial financing a continued support from public funding institutions as well as from industry will be necessary to succeed in this.

It remains our challenge and also our ultimate task to continue the search for solutions to fight degenerative tissue and organ malfunction through the interdisciplinary approach of various disciplines in Tissue Engineering and Regenerative Medicine.

\section{References}

1. Vacanti CA 2006) The history of tissue engineering. J Cell Mol Med 10: 569 576 .

2. Vacanti $J(2010)$ Tissue engineering and regenerative medicine: from first principles to state of the art. J Pediatr Surg 45: 291-294.

3. Atala A (2012) Human embryonic stem cells: early hints on safety and efficacy Lancet. 
4. Glotzbach JP, Wong VW, Gurtner GC, Longaker MT (2011) Regenerative medicine. Curr Probl Surg 48: 148-212.

5. Polykandriotis E, Popescu LM, Horch RE (2010) Regenerative medicine: then and now--an update of recent history into future possibilities. J Cell Mol Med 14: $2350-2358$.

6. Polak DJ (2010) Regenerative medicine. Opportunities and challenges: a brie overview. J R Soc Interface 6: S777-781.

7. Horch RE, Kopp J, Kneser U, Beier J, Bach AD (2005) Tissue engineering of cultured skin substitutes. J Cell Mol Med 9: 592-608.

8. Horch RE, Bannasch H, Stark GB (2001) Transplantation of cultured autologous keratinocytes in fibrin sealant biomatrix to resurface chronic wounds. Transplant Proc 33: 642-644.

9. Horch RE, Debus M, Wagner G, Stark GB (2000) Cultured human keratinocytes on type I collagen membranes to reconstitute the epidermis. Tissue Eng 6: 5367.

10. Horch RE, Andree C, Kopp J, Tánczos E, Voigt M, et al. (2000) Gene therapy perspectives in modulation of wound healing. Zentralbl Chir 125: 74-78.

11. Horch RE, Bannasch H, Kopp J, Andree C, Stark GB (1998) Single-cel suspensions of cultured human keratinocytes in fibrin-glue reconstitute the epidermis. Cell Transplant 7: 309-317.

12. Horch RE (2006) Future perspectives in tissue engineering. J Cell Mol Med 10: $4-6$

13. Will J, Gerhardt LC, Boccaccini AR (2011) Bioactive Glass-Based Scaffolds for Bone Tissue Engineering. Adv Biochem Eng Biotechnol.

14. Yunos DM, Ahmad Z, Salih V, Boccaccini AR (2011) Stratified scaffolds for osteochondral tissue engineering applications: Electrospun PDLLA nanofibre coated Bioglass(R)-derived foams. J Biomater Appl.

15. Arkudas A, Beier JP, Heidner K, Tjiawi J, Polykandriotis E, et al. (2007) Axia prevascularization of porous matrices using an arteriovenous loop promotes survival and differentiation of transplanted autologous osteoblasts. Tissue Eng 13: $1549-1560$

16. Arkudas A, Pryymachuk G, Beier JP, Weigel L, Körner C, et al. (2012) Combination of extrinsic and intrinsic pathways significantly accelerates axial vascularization of bioartificial tissues. Plast Reconstr Surg 129: 55e-65e.

17. Beier JP, Hess A, Loew J, Heinrich J, Boos AM, et al. (2011) De novo generation of an axially vascularized processed bovine cancellous-bone substitute in the sheep arteriovenous-loop model. Eur Surg Res 46: 148-155.

18. Zhang J, Niu C, Ye L, Huang H, He X, et al. (2003) Identification of the haematopoietic stem cell niche and control of the niche size. Nature 425: 836841.

19. Viero Nora CC, Camassola M, Bellagamba B, Ikuta N, Christoff AP, et al. (2011) Molecular Analysis of the Differentiation Potential of Murine Mesenchyma Stem Cells from Tissues of Endodermal or Mesodermal Origin. Stem Cells Dev.

20. de Barros AP, Takiya CM, Garzoni LR, Leal-Ferreira ML, Dutra HS, et al. (2010) Osteoblasts and bone marrow mesenchymal stromal cells control hematopoietic stem cell migration and proliferation in 3D in vitro model. PLoS One 5: e9093.

21. Pilgaard L, Lund P, Rasmussen JG, Fink T, Zachar V (2008) Comparative analysis of highly defined proteases for the isolation of adipose tissue-derived stem cells. Regen Med 3: 705-715.

22. Boos AM, Loew JS, Deschler G, Arkudas A, Bleiziffer O, et al. (2011) Directly auto-transplanted mesenchymal stem cells induce bone formation in a ceramic bone substitute in an ectopic sheep model. J Cell Mol Med 15: 1364-1378.

23. Tuljapurkar SR, Jackson JD, Brusnahan SK, O'Kane BJ, Shar JG (2012) Characterization of a mesenchymal stem cell line that differentiates to bone and provides niches supporting mouse and human hematopoietic stem cells. Stem Cell Discovery 2: 5-14.

24. Zhang D, Fan GC, Zhou X, Zhao T, Pasha Z, et al. (2008) Over-expression of CXCR4 on mesenchymal stem cells augments myoangiogenesis in the infarcted myocardium. J Mol Cell Cardiol 44: 281-292.

25. Peschle C, Condorelli G (2005) Stem cells for cardiomyocyte regeneration: state of the art. Ann N Y Acad Sci 1047: 376-385.

26. Khan M, Mohsin S, Khan SN, Riazuddin S (2011) Repair of senescent myocardium by mesenchymal stem cells is dependent on the age of donor mice. J Cell Mol Med 15: 1515-1527.

27. Mayorga ME, Penn MS (2011) miR-145 is differentially regulated by TGFbeta1 and ischemia and targets disabled-2 expression and wnt/beta-catenin activity. $\mathrm{J}$ Cell Mol Med.

28. Wang W, Li W, Ou L, Flick E, Mark P, et al. (2011) Polyethylenimine-mediated gene delivery into human bone marrow mesenchymal stem cells from patients. J Cell Mol Med 15: 1989-1998.

29. Wen Z, Zheng S, Zhou C, Yuan W, Wang J, et al. (2011) Bone marrow mesenchymal stem cells for post-myocardial infarction cardiac repair: microRNAs as novel regulators. J Cell Mol Med.

30. Zhang H, Hou JF, Shen Y, Wang W, Wei YJ, et al. (2010) Low level lase irradiation precondition to create friendly milieu of infarcted myocardium and enhance early survival of transplanted bone marrow cells. J Cell Mol Med 14 1975-1987.

31. Atala A (2009) Regenerative medicine and tissue engineering in urology. Urol Clin North Am 36: 199-209.

32. Atala A (2012) Regenerative medicine strategies. J Pediatr Surg 47: 17-28.

33. Horch RE, Pepescu LM, Vacanti C, Maio G (2008) Ethical issues in cellular and molecular medicine and tissue engineering. J Cell Mol Med 12: 1785-1793.

34. Roemeling-van Rhijn M, Weimar W, Hoogduijn MJ (2012) Mesenchymal stem cells: application for solid-organ transplantation. Curr Opin Organ Transplant 17: $55-62$

35. Cossetti C, Alfaro-Cervello C, Donega M, Tyzack G, Pluchino S (2012) New perspectives of tissue remodelling with neural stem and progenitor cell-based therapies. Cell Tissue Res.

36. Turshen M (1976) An analysis of the medical supply industries. Int J Health Serv 6: 271-294.

37. McIntyre AM (1998) Burden of illness review of obesity: are the true costs realised? J R Soc Health 118: 76-84.

38. Brandt FS, Cazzaniga A, Hann M (2011) Cosmeceuticals: current trends and market analysis. Semin Cutan Med Surg 30: 141-143.

39. Nweke OC, Lee C (2011) Achieving environmental justice: perspectives on the path forward through collective action to eliminate health disparities. Am J Public Health 101: S6-8.

40. Lee R, Mason A (2010) Some macroeconomic aspects of global population aging. Demography 47: S151-172.

41. Arkudas A, Tjiawi J, Saumweber A, Beier JP, Polykandriotis E, et al. (2009) Evaluation of blood vessel ingrowth in fibrin gel subject to type and concentration of growth factors. J Cell Mol Med 13: 2864-2874

42. Klumpp D, Horch RE, Kneser U, Beier JP (2010) Engineering skeletal muscle tissue--new perspectives in vitro and in vivo. J Cell Mol Med 14: 2622-2629.

43. Kneser U, Schaefer DJ, Polykandriotis E, Horch RE (2006) Tissue engineering of bone: the reconstructive surgeon's point of view. J Cell Mol Med 10: 7-19.

44. Polykandriotis E, Arkudas A, Horch RE, Sturzl M, Kneser U (2007) Autonomously vascularized cellular constructs in tissue engineering: opening a new perspective for biomedical science. J Cell Mol Med 11: 6-20.

45. Polykandriotis E, Euler S, Arkudas A, Pryymachuk G, Beier JP, et al. (2009) Regression and persistence: remodelling in a tissue engineered axial vascular assembly. J Cell Mol Med 13: 4166-4175.

46. Beier JP, Klumpp D, Rudisile M, Dersch R, Wendorff JH, et al. (2009) Collagen matrices from sponge to nano: new perspectives for tissue engineering of skeletal muscle. BMC Biotechnol 9: 34

47. Misra SK, Ansari T, Mohn D, Valappil SP, Brunner TJ, et al. (2010) Effect of nanoparticulate bioactive glass particles on bioactivity and cytocompatibility of poly(3-hydroxybutyrate) composites. J R Soc Interface 7: 453-465.

48. Dodd IB, Micheelsen MA, Sneppen K, Thon G (2007) Theoretical analysis of epigenetic cell memory by nucleosome modification. Cell 129: 813-822.

49. Redei GP, Koncz C, Phillips JD (2006) Changing images of the gene. Adv Genet 56: 53-100.

50. Nicol-Benoît F, Le-Goff P, Le-Dréan Y, Demay F, Pakdel F, et al. (2012 Epigenetic memories: structural marks or active circuits? Cell Mol Life Sci. 
Citation: Horch RE (2012) New Developments and Trends in Tissue Engineering: An Update. J Tissue Sci Eng 3:e110. doi:10.4172/2157$7552.1000 \mathrm{e} 110$

51. Cismasiu VB, Radu E, Popescu LM (2011) miR-193 expression differentiates telocytes from other stromal cells. J Cell Mol Med 15: 1071-1074.

52. Cretoiu SM, Simionescu AA, Caravia L, Curici A, Cretoiu D, et al. (2011) Complex effects of imatinib on spontaneous and oxytocin-induced contractions in human non-pregnant myometrium. Acta Physiol Hung 98: 329-338.

53. Gherghiceanu M, Manole CG, Popescu LM (2010) Telocytes in endocardium: electron microscope evidence. J Cell Mol Med 14: 2330-2334.

54. Gherghiceanu M, Popescu LM (2010) Cardiomyocyte precursors and telocytes in epicardial stem cell niche: electron microscope images. J Cell Mol Med 14 871-877

55. Gherghiceanu M, Popescu LM (2011) Heterocellular communication in the heart: electron tomography of telocyte-myocyte junctions. J Cell Mol Med 15: 1005-1011.

56. Hinescu ME, Gherghiceanu M, Suciu L, Popescu LM (2011) Telocytes in pleura: two- and three-dimensional imaging by transmission electron microscopy. Cell Tissue Res 343: 389-397.

57. Mandache E, Gherghiceanu M, Macarie C, Kostin S, Popescu LM (2010) Telocytes in human isolated atrial amyloidosis: ultrastructural remodelling. $\mathrm{J}$ Cell Mol Med 14: 2739-2747.

58. Manole CG, Cismasiu V, Gherghiceanu M, Popescu LM (2011) Experimental acute myocardial infarction: telocytes involvement in neo-angiogenesis. J Cell Mol Med 15: 2284-2296.

59. Nicolescu MI, Bucur A, Dinca O, Rusu MC, Popescu LM (2011)Telocytes in Parotid Glands. Anat Rec (Hoboken) 295: 378-385.
60. Nicolescu MI, Popescu LM (2012) Telocytes in the Interstitium of Human Exocrine Pancreas: Ultrastructural Evidence. Pancreas.

61. Popescu LM, Manole CG, Gherghiceanu M, Ardelean A, Nicolescu1 MI, et al. (2010) Telocytes in human epicardium. J Cell Mol Med 14: 2085-2093.

62. Popescu LM, Manole E, Serboiu CS, Manole CG, Suciu LC, et al. (2011) Identification of telocytes in skeletal muscle interstitium: implication for muscle regeneration. J Cell Mol Med 15: 1379-1392.

63. Suciu L, Nicolescu MI, Popescu LM (2010) Cardiac telocytes: serial dynamic images in cell culture. J Cell Mol Med 14: 2687-2692.

64. Suciu L, Popescu LM, Gherghiceanu M, Regalia T, Nicolescu MI, et al. (2010) Telocytes in human term placenta: morphology and phenotype. Cells Tissues Organs 192: 325-339.

65. Suciu LC, Popescu BO, Kostin S, Popescu LM (2011) PDGFR-beta positive telocytes in skeletal muscle interstitium. J Cell Mol Med.

66. Popescu LM, Gherghiceanu M, Suciu LC, Manole CG, Hinescu ME (2011) Telocytes and putative stem cells in the lungs: electron microscopy, electron tomography and laser scanning microscopy. Cell Tissue Res 345: 391-403.

67. Popescu LM, Faussone-Pellegrini MS (2010) TELOCYTES - a case of serendipity: the winding way from Interstitial Cells of Cajal (ICC), via Interstitial Cajal-Like Cells (ICLC) to TELOCYTES. J Cell Mol Med 14: 729-740.

68. H Hutmacher DW, Horch RE, Loessner D, Rizzi S, Sieh S, et al. (2009) Translating tissue engineering technology platforms into cancer research. $J$ Cell Mol Med 13: 1417-1427. 